\title{
Effect of Nutrient Management Practices on Yield and Yield Attributes of Groundnut and Available Nutrient Status in Soil after Harvest in Groundnut + Baby Corn Intercropping System under Changing Climate
}

\author{
Nishith Das $^{1 *}$, B. K. Desai ${ }^{2}$, B. G. Koppalkar ${ }^{3}$, N. Ananda ${ }^{4}$ \\ and L. M. Garnayak ${ }^{1}$ \\ ${ }^{1}$ Department of Agronomy, College of Agriculture, OUAT, Bhubaneswar-751003, India \\ ${ }^{2}$ Directorate of Research, University of Agricultural Sciences, Raichur, India \\ ${ }^{3}$ Department of Agronomy, College of Agriculture, UAS, Raichur, India \\ ${ }^{4}$ AICRP(Linseed), MARS, UAS, Raichur ${ }^{4}-584104$, India \\ *Corresponding author
}

\section{A B S T R A C T}

Keywords

Intercropping, groundnut equivalent yield, RDF and shelling percentage

Article Info

Accepted:

12 February 2020

Available Online:

10 March 2020
A field experiment was undertaken to study the effect of nutrient management on yield and yield attributes of groundnut and available nutrient status in soil after harvest in groundnut + baby corn (3:1) intercropping system at MARS Raichur, during the kharif 2018 with eight treatments replicated thrice in a randomized complete block design. Groundnut + baby corn (3:1) intercropping system receiving 125 per cent RDF only to groundnut produced the higher number of filled pods plant ${ }^{-1}(14.08), 100$ kernel weight $(27.50 \mathrm{~g})$, shelling percentage $(65.08$ $\%)$ and pod yield (1170 kg/ha), which was at par with the treatment that received 100 per cent RDF to both groundnut and baby corn with corresponding values of (13.90, $26.98 \mathrm{~g}, 64.62 \%$ and $1126 \mathrm{~kg} / \mathrm{ha}$, respectively).Treatment fertilized with 100 per cent RDF to both the component crops in groundnut + baby corn (3:1) intercropping system resulted in higher groundnut equivalent yield $(2237 \mathrm{~kg} / \mathrm{ha})$ and was at par with the groundnut + baby corn intercropping system receiving 50 per cent RDF of groundnut and 100 percent RDF of baby corn with groundnut equivalent yield of $2104 \mathrm{~kg} / \mathrm{ha}$.Groundnut + baby corn (3:1) system with 100 percent RDF to both the crops registered higher soil available nitrogen, phosphorus and potassium $(214.4,22.5$ and $228.9 \mathrm{~kg} / \mathrm{ha}$, respectively).

\section{Introduction}

Time and space utilization in agriculture through intercropping is one of the viable options to produce a greater yield on a given piece of land by making use of resources or ecological processes that would otherwise not be utilized by a single crop. Legume in an intercropping system not only provides nitrogen to the associated crops but also 
increased the amount of humus in the soil due to decaying of crop remains.Baby cornwith shorter lifecycle and having single stem with upright growing habit is best suitable for intercropping and being a commercial crop, it fetches high net returns to the farmers and thereby gaining importance among the farming community in recent years. Demand of groundnut by 2020 is expected to reach nearly about 14 million tones whereas the present production level is around 6.9 million tonnes. Therefore, a gap of about 7.1 million tones needs to be filled and this can be possible if the production rate will increase by 2.2 percent per annum (Noman et al., 2016). Sustainable groundnut production can be achieved by diversifying the groundnut-based cropping system and nutrient management. In cropping system, intensive use of fertilizers is practiced to enhance the productivity and profitability (Kumar et al., 2008).Judicious use of fertilizers is highly necessary to save extra amount of fertilizers and to have favourable effect on crop environment

\section{Materials and Methods}

A field experiment was conducted at MARS, College of Agriculture, Raichur during kharif2018,onsandy clay loam soil with $\mathrm{pH}$ of 7.2 , electrical conductivity of $0.31 \mathrm{dS} \mathrm{m}^{-1}$ and available $\mathrm{N}, \mathrm{P}$ and $\mathrm{K}$ of 226.8, 27.2 and 254.6 $\mathrm{kg} / \mathrm{ha}$, respectively. The groundnut variety $\mathrm{K}$ 9maturing in 115 to 125 days and baby corn hybrid C.P. B-472 of 65-70 days duration were sown on 23 July, 2018 with a spacing of $30 \mathrm{~cm} \times 10 \mathrm{~cm}$ for groundnut (sole and intercrop) and $60 \mathrm{~cm} \times 20 \mathrm{~cm}$ for baby corn. Groundnut was intercropped with baby corn in 3:1.Required quantity of nitrogen, phosphorus and potassium were applied in the form of urea $(46 \% \mathrm{~N})$, diammonium phosphate (18-46-0) and muriate of potash $\left(\begin{array}{lll}60 & \mathrm{~K}_{2} \mathrm{O}\end{array}\right)$, respectively. Recommended dose of fertilizers for the sole crop of groundnut was $25-75-37.5 \mathrm{~kg} \mathrm{~N}, \mathrm{P}_{2} \mathrm{O}_{5}$ and
$\mathrm{K}_{2} \mathrm{O} /$ haand for sole baby corn was $150-60-40$ $\mathrm{kg} \mathrm{N}, \mathrm{P}_{2} \mathrm{O}_{5}$ and $\mathrm{K}_{2} \mathrm{O} /$ ha.Eight treatments were replicated thrice in a Randomized Complete Block Design. The treatments were $T_{1}-$ Sole groundnut with $100 \% \mathrm{RDF} ; \mathrm{T}_{2^{-}}$Sole baby corn with $100 \%$ RDF; $\mathrm{T}_{3}$ - groundnut + baby corn (3:1) with $100 \%$ RDF to both the crops; $\mathrm{T}_{4}$ - groundnut + baby corn $(3: 1)$ with $100 \%$ RDF only to groundnut; $\mathrm{T}_{5}-$ groundnut + baby corn (3:1) with $125 \%$ RDF only to groundnut; $\mathrm{T}_{6^{-}}$groundnut + baby corn $(3: 1)$ with $100 \%$ RDF to groundnut and $50 \%$ RDF to baby corn; $\mathrm{T}_{7}$ - groundnut + baby corn (3:1) with $50 \%$ RDF to groundnut and $100 \%$ RDF to baby corn; $\mathrm{T}_{8}$ - groundnut + baby corn $(3: 1)$ with $50 \%$ RDF to both the crops. The crops were raised under rainfed condition with adequate plant protection measures.

\section{Results and Discussion}

Yield attributes i.e. number of filled pods per plant, 100 kernel weights (g) and shelling percentage of groundnut

Among the yield attributing characters, number of filled pods per plant (15.22) and 100 kernel weight (28.00 g) were significantly higher under sole crop of groundnut as compared to intercropping treatments (11.69 to 14.08 and 24.08 to $27.50 \mathrm{~g}$, respectively). Highest shelling percentage also recorded under the sole groundnut crop fertilized with 100 per cent RDF. The lower yield attributes of groundnut under intercropping system may be due to increased plant population pressure of main and intercrop together resulting in increased competition for nutrients, water, space and light compared to sole crop.

Treatment receiving 125 per cent RDF only to groundnut in 3:1 groundnut +baby corn intercropping system $\left(\mathrm{T}_{5}\right)$ recorded higher number of filled pods per plant, highest kernel weight and it was at par with $\mathrm{T}_{3}$ i.e. $100 \%$ $\mathrm{RDF}$ to both groundnut and baby corn. It was 
due to higher availability of nutrients to groundnut under these treatments. Due to higher availability of nutrients under these treatments made more vigorous growth of crop which was evident from higher leaf area and more dry matter production than rest of the intercropped treatments. These results are in line with those reported by Tomar et al., (2007) and Sibhatu et al., (2016).The same trend was also followed in case of shelling percentage of groundnut. Higher shelling percentage was due to more dry matter production and there after efficient translocation of food from source to sink (kernels). These results are in line with the results reported by Hussaini and Mohammed (2003).

\section{Pod yield of groundnut ( $\mathrm{kg} / \mathrm{ha})$}

The treatment receiving 100 per cent RDF to sole groundnut $\left(T_{1}\right)$ resulted in significantly higher pod yield (1516 kg ha-1) as compared to other treatments. Sole groundnut produced higher pod yield of $1516 \mathrm{~kg} / \mathrm{ha}$ and was superior over intercropped treatments which ranged from 935 to $1170 \mathrm{~kg} / \mathrm{ha}$ and the reduction in pod yield of groundnut due to intercropping with baby corn was 23 to 39 per cent as compared to the sole crop of groundnut.

The reasons attributed for higher yields in sole crop of groundnut over intercropped were due to superior growth parameters and yield attributing characters. Groundnut + baby corn 3:1 intercropping system with 125 per cent RDF only to groundnut $\left(\mathrm{T}_{5}\right)$ recorded higher pod yield and was at par with $\mathrm{T}_{3}(100$ $\%$ RDF to both crops in 3:1 groundnut + baby corn intercropping system). This was due to better growth attributes like more leaf area and dry matter production and yield attributing (i.e. number of pods per plant, pod weight plant $^{-1}$ and 100 kernel weight) characters over other treatments. Similar results were reported by Bhagat et al., (2007). Treatment receiving $50 \%$ RDF to both crops in 3:1 groundnut + baby corn intercropping $\left(\mathrm{T}_{8}\right)$ system resulted in lowest pod yield of groundnut as compared to other treatments.

This was mainly due to $50 \%$ reduction in supply of RDF to groundnut which resulted in non-availability of the nutrients especially phosphorous during critical crop growth stages, so as a result there might be reduction in root growth, improper development of gynophores, reduction in uptake of nutrients and led to the competition for the nutrient from both the component crops.

\section{Groundnut equivalent yield (kg/ha)}

Groundnut + baby corn (3:1) intercropping system produced 23.4 to 47.5 per cent higher groundnut equivalent yield than sole groundnut. But application of 100 per cent $\mathrm{RDF}$ to sole baby corn i.e. $\left(\mathrm{T}_{2}\right)$ produced the highest groundnut equivalent yield (2321 $\mathrm{kg} / \mathrm{ha}$ ) which was at par with groundnut + baby corn supplied with 100 per cent RDF to both the crops $(2237 \mathrm{~kg} / \mathrm{ha})$. Higher yield potential and price of baby corn resulted in higher groundnut equivalent yield of sole baby corn fertilized with 100 per cent RDF.

In turn the latter treatment was at par with the groundnut + baby corn intercropping system receiving 50 per cent RDF of groundnut and 100 percent RDF of baby corn $\left(\mathrm{T}_{7}\right)$ with groundnut equivalent yield of $2104 \mathrm{~kg} / \mathrm{ha}$.

This was due to higher pod yields of groundnut and cob yields of baby corn owing to optimum nutrient availability coupled with higher price of both the crops which was in conformity with the findings of Priya et al., (2011). Sole groundnut with 100 per cent RDF resulted in the lowest groundnut equivalent yield (1517 $\mathrm{kg} / \mathrm{ha})$ compared to any of the intercropping treatments. 
Table.1 Number of filled pods plant ${ }^{-1}$, number of unfilled pods plant ${ }^{-1}, 100$-kernel weight and shelling percentage, pod yield and groundnut equivalent yield as influenced by nutrient management practices in groundnut + baby corn (3:1) intercropping system

\begin{tabular}{|c|c|c|c|c|c|c|}
\hline Treatments & $\begin{array}{l}\text { No. of filled } \\
\text { pods plant }^{-1}\end{array}$ & $\begin{array}{l}\text { No. of } \\
\text { unfilled } \\
\text { pods plant }^{-1}\end{array}$ & $\begin{array}{l}\text { Kernel } \\
\text { wt. (g) }\end{array}$ & $\begin{array}{l}\text { Shelli } \\
\text { ng } \\
(\%)\end{array}$ & $\begin{array}{l}\text { Pod yield of } \\
\text { groundnut } \\
\text { (kg/ha) }\end{array}$ & $\begin{array}{l}\text { Groundnut } \\
\text { equivalent } \\
\text { yield (kg/ha) }\end{array}$ \\
\hline $\mathrm{T}_{1}$ : Sole Groundnut with $100 \%$ RDF & 15.22 & 2.42 & 28.00 & 68.86 & 1516 & 1517 \\
\hline $\mathrm{T}_{2}:$ Sole Baby corn with $100 \%$ RDF & - & - & - & - & - & 2321 \\
\hline $\begin{array}{l}T_{3}: \text { Groundnut }+ \text { baby corn }(3: 1) \text { with } 100 \% \\
\text { RDF to both the crops }\end{array}$ & 13.90 & 3.47 & 26.98 & 64.62 & 1126 & 2237 \\
\hline $\begin{array}{l}T_{4}: \text { Groundnut + baby corn }(3: 1) \text { with } 100 \% \\
\text { RDF only to groundnut }\end{array}$ & 12.83 & 4.76 & 26.25 & 61.83 & 1088 & 1872 \\
\hline $\begin{array}{l}\text { T }_{5}: \text { Groundnut + baby corn }(3: 1) \text { with } 125 \% \\
\text { RDF only to groundnut }\end{array}$ & 14.08 & 3.18 & 27.50 & 65.08 & 1170 & 1977 \\
\hline $\begin{array}{l}\text { T }_{6}: \text { Groundnut }+ \text { baby corn }(3: 1) \text { with } 100 \% \\
\text { RDF to groundnut and } 50 \% \text { RDF to baby } \\
\text { corn }\end{array}$ & 12.58 & 5.25 & 25.64 & 61.14 & 1062 & 2074 \\
\hline 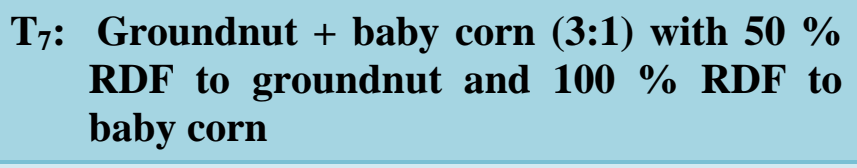 & 12.09 & 6.05 & 24.66 & 60.47 & 1011 & 2104 \\
\hline $\begin{array}{l}T_{8}: \text { Groundnut }+ \text { baby corn }(3: 1) \text { with } 50 \% \\
\text { RDF to both the crops }\end{array}$ & 11.69 & 6.18 & 24.08 & 60.01 & 935 & 1895 \\
\hline S. Em. \pm & 0.27 & 0.25 & 0.18 & 0.22 & 36 & 44 \\
\hline C.D. $(p=0.05)$ & 0.81 & 0.77 & 0.54 & 0.68 & 110 & 135 \\
\hline
\end{tabular}


Table.2 Effect of nutrient management practices on available soil nitrogen, phosphorus and potassium in soil after harvest in groundnut + baby corn (3:1) intercropping system

\begin{tabular}{|c|c|c|c|}
\hline Treatments & $\begin{array}{l}\text { Available soil } \\
\text { nitrogen } \\
\text { (kg/ha) }\end{array}$ & $\begin{array}{c}\text { Available } \\
\text { phosphorous } \\
\text { (kg/ha) }\end{array}$ & $\begin{array}{c}\text { Available } \\
\text { potassium } \\
\text { ( kg/ha) }\end{array}$ \\
\hline $\mathrm{T}_{1}$ : Sole Groundnut with $100 \% \mathrm{RDF}$ & 224.7 & 19.3 & 198.6 \\
\hline$T_{2}$ : Sole Baby corn with $100 \%$ RDF & 148.3 & 17.8 & 192.8 \\
\hline$T_{3}:$ Groundnut + baby corn $(3: 1)$ with $100 \%$ RDF to both the crops & 212.4 & 22.5 & 228.9 \\
\hline$T_{4}:$ Groundnut + baby corn $(3: 1)$ with $100 \%$ RDF only to groundnut & 176.5 & 17.2 & 193.8 \\
\hline $\mathrm{T}_{5}$ : Groundnut + baby corn (3:1) with $125 \%$ RDF only to groundnut & 182.3 & 18.2 & 195.2 \\
\hline $\begin{array}{l}\text { T }_{6}: \text { Groundnut + baby corn }(3: 1) \text { with } 100 \% \text { RDF to groundnut and } 50 \% \text { RDF } \\
\text { to baby corn }\end{array}$ & 202.3 & 20.6 & 210.4 \\
\hline $\begin{array}{l}\mathrm{T}_{7}: \text { Groundnut + baby corn }(3: 1) \text { with } 50 \% \mathrm{RDF} \text { to groundnut and } 100 \% \mathrm{RDF} \\
\text { to baby corn }\end{array}$ & 214.6 & 21.1 & 218.5 \\
\hline$T_{8}:$ Groundnut + baby corn $(3: 1)$ with $50 \%$ RDF to both the crops & 198.7 & 19.0 & 196.2 \\
\hline S. Em. \pm & 3.8 & 0.8 & 4.8 \\
\hline C.D. $(p=0.05)$ & 11.4 & 2.5 & 14.3 \\
\hline
\end{tabular}


Available nitrogen, phosphorus and potassium ( $\mathrm{kg} / \mathrm{ha})$ after harvest of crops

Higher values of available soil nitrogen, phosphorus and potassium (224.7 and 19.3 and $228.2 \mathrm{~kg} / \mathrm{ha}$ ) were estimated under sole groundnut when fertilized with 100 per cent RDF $\left(\mathrm{T}_{1}\right)$. But among the intercropping treatments, groundnut + baby corn (3:1) system with 100 per cent RDF to both the crops registered higher soil available nitrogen, phosphorus and potassium (214.4, 22.5 and $228.9 \mathrm{~kg} / \mathrm{ha}$, respectively) but was at par with application of 50 per cent RDF to groundnut and 100per cent RDF to baby corn (212.6, 21.1 and $218.5 \mathrm{~kg} / \mathrm{ha}$, respectively).

Higher nitrogen content in the soil might be due to the greater nitrogen fixing ability of groundnut crop. Similarly, phosphorus availability in soil was high due to release of more amount of fixed $\mathrm{P}$ by the action of rhizosphere micro-organisms. Overall improvement of available $\mathrm{K}$ status in surface soil might be due to the ability of tap root of groundnut to absorb $\mathrm{K}$ from deeper layer of soil and enriched surface soil by shedding nutrient rich leaves which upon decomposition release nutrients into the surface soil (Singh, 2005). However, application of 100 per cent RDF to sole baby corn resulted in lower values of available N, P and $\mathrm{K}(148.3$ and 17.8 and $193.8 \mathrm{~kg} / \mathrm{ha})$ as compared to other treatments due to exhaustive nature of baby corn.

Treatment receiving 125 per cent RDF only to groundnut in 3:1 groundnut +baby corn intercropping system $\left(T_{5}\right)$ recorded higher number of filled pods per plant, highest kernel weight and it was at par with the treatments that was fertilized with 100 per cent RDF to both groundnut and baby corn in groundnut + baby corn (3:1) intercropping system. Similar trend was also seen in case of pod yield of groundnut. Among the intercropping treatments, groundnut + baby corn (3:1) system with 100 per cent RDF to both the crops registered higher soil available nitrogen, phosphorus and potassium $(214.4,22.5$ and $228.9 \mathrm{~kg} / \mathrm{ha}$, respectively) but was at par with application of 50 per cent RDF to groundnut and 100 per cent RDF to baby corn (212.6, 21.1 and $218.5 \mathrm{~kg} / \mathrm{ha}$, respectively). Among the different intercropped treatments, groundnut + baby corn supplied with 100 per cent RDF to both the crops registered significantly higher groundnut equivalent yield $(2237 \mathrm{~kg} / \mathrm{ha})$ and was at par with the groundnut + baby corn intercropping system receiving 50 per cent RDF of groundnut and 100 percent RDF of baby corn $\left(\mathrm{T}_{7}\right)$ with groundnut equivalent yield of $2104 \mathrm{~kg} / \mathrm{ha}$. Thus, in groundnut + baby corn (3:1) intercropping system 50 per cent RDF can be save in case of groundnut and that will help to increase the net returns of the farmer and also in the changing climatic situation it reduces the excessive use of chemical fertilizer as a result it maintain the soil as well as the ecosystem healthy.

\section{References}

Bhagat, S. B., Chavan, S. A., Zagade, M. V. and Dahiphale, A. V., 2007, Intercropping groundnut and sweet corn at different fertility levels and row proportion. Indian J. Crop Sci., 1 (1-2): 151-153.

Hussaini, M. A. and Mohammed, S. G., 2003, Productivity of maize-groundnut mixture in relation to fertilizer and planting pattern in a Guinea Savanna ecology. J. Sus. Agri. Environ., 5 (1): 52-62.

Kumar, A., Tripathi, H. R., Yadav, R. A. and Yadav, D. S., 2008, Diversification of rice (Oryza sativa)-wheat (Triticum aestivum) cropping system for sustainable production in eastern Uttar pradesh. Indian J. Agron., 53 (1): 18-21. 
Noman, H. M., Rana, D. S. and Paul, T., 2016, Sulphur and zinc management in groundnut (Arachis hypogaea)-wheat (Triticum aestivum) cropping system. Indian J. Agril. Sci., 86 (4): 441-7.

Priya, R. S., Yassin, M. M., Maheswari, J. and Sangeetha, S. P., 2011, Influence of NPK fertilization on productivity and oil yield of groundnut (Arachis hypogaea) and sunflower (Helianthus annuus) in intercropping system under irrigated condition. Indian J. Agril. Res., 4 (2): 97-106.

Sibhatu, B., Guesh, T. and Melesse, H., 2016, Response of groundnut (Arachis hypogaea L.) to different rates of phosphorus fertilizer at TanquaAbergelle District, Northern Ethiopia. Basic Res. J. Agric. Sci. Rev., 5 (1): 2429.

Singh, V. K., 2005, Nutrient management in wheat-based cropping system. Indian $J$. Agril. Sci., 32(1): 212-217.

Tomar, S. K., Singh, H. P. and Ahlawat, I. P. S., 2007, Dry matter accumulation and nitrogen uptake in wheat based intercropping systems as affected by $\mathrm{N}$ fertilizer levels. Indian J. Agron., 42 (1): 33-37.

\section{How to cite this article:}

Nishith Das, B. K. Desai, B. G. Koppalkar, N. Ananda and Garnayak. L. M. 2020. Effect of Nutrient Management Practices on Yield and Yield Attributes of Groundnut and Available Nutrient Status in Soil after Harvest in Groundnut + Baby Corn Intercropping System under Changing Climate. Int.J.Curr.Microbiol.App.Sci. 9(03): 1702-1708. doi: https://doi.org/10.20546/ijcmas.2020.903.198 